\title{
Effect of Intraoperative Neuromonitoring on Voice Quality in Total Thyroidectomy
}

\section{Total Tiroidektomide Intraoperatif Sinir Monitörizasyonunun Ses Kalitesine Etkisi}

\author{
๑ Erdinç Çekiç, ๑ Turgut Dönmez* , ๑ Özgür Sürmelioğlu**, ๑ Sina Ferahman***, \\ (1) Engin Hatipoğlu***, ( ) Ahmet Kocakuşak**** \\ Istanbul Lütfiye Nuri Burat State Hospital, Clinic of Otorhinolaryngology, Istanbul, Turkey \\ *istanbul Lütfiye Nuri Burat State Hospital, Clinic of General Surgery, İstanbul, Turkey \\ **Çukurova University Faculty of Medicine, Department of Otorhinolaryngology, Adana, Turkey \\ ***istanbul University Cerrahpaşa Faculty of Medicine, Department of General Surgery, istanbul, Turkey \\ $* * * *$ University of Health Sciences, Haseki Training and Research Hospital, Clinic of General Surgery, Istanbul, Turkey
}

\section{Abstract}

Aim: Thyroid gland surgery has a risk of serious complications. Advancements in technology have led to improvements in complications but significant challenges to preserving voice and airway function still remain. The purpose of this study was to evaluate voice quality following total thyroidectomy under neuromonitoring and effect of intraoperative neuromonitoring (IONM) on identification of the recurrent laryngeal nerve (RLN) and external branch of the superior laryngeal nerve (EBSLN).

Methods: A total of 80 patients scheduled for total thyroidectomy between May 2015 and March 2016 were included in the study. All the RLNs and EBSLNs were identified. Voice assessment included preoperative and postoperative fiberoptic laryngoscopy, analysis of Jitter, Shimmer, and fundamental frequency and the Voice Handicap index-10.

Results: Eighty patients were included in this study (71 females, nine males). There was no significant difference between mean initial and post-dissection electromyographic amplitudes with RLN and EBSLN stimulation. The rate of postoperative transient RLN palsy per nerve at risk was $4.375 \%(7 / 160)$ and null for permanent RLN palsy $(0 \%$, 0/160).

Conclusion: Both subjective and objective assessments revealed preservation of voice quality in patients after total thyroidectomy under neuromonitoring. IONM may be used effectively and safely in order to identify the EBSLN during thyroid surgery.

Keywords: Neuromonitoring, thyroidectomy, voice quality
Amaç: Tiroid ameliyatının olası ciddi komplikasyonları vardır. Teknolojideki ilerlemeler komplikasyonların azalmasına neden olmuştur ama hava yolu ve sesle ilgili önemli sorunlar halen devam etmektedir. Bu çalışmanın amacl, intraoperatif sinir monitörizasyonunun (IONM) rekürren larengeal sinirin (RLN) ve superior larengeal sinirin eksternal dalının (EBSLN) tanınmasıyla total tiroidektomiyi takiben ses kalitesinin değerlendirilmesidir.

Yöntemler: Mayıs 2015 ve Mart 2016 tarihleri arasında total tiroidektomi ameliyatı planlanan 80 hasta çalısmaya dahil edildi. Olgulardaki tüm RLN ve EBSLN traseleri başarı ile belirlendi. Ses kalite değerlendirmeleri ameliyat öncesi ve sonrası dönemde; fiberoptik laringoskopi, Jitter, Shimmer analizleri, temel fundamental frekans ve Ses Handikap indeksi-10 ile değerlendirildi.

Bulgular: Seksen hasta (71 kadın/dokuz erkek) çalışmaya dahil edildi. Diseksiyon başlangıç ve sonrasında hem RLN hem de EBSLN için ortalama elektromiyografi amplitüdünde anlamlı ölçüde fark yoktu. Ameliyat sonrası geçici RLN felci oranı (7/160) \%4,375 iken, kalıı RLN felcine $(\% 0,0 / 160)$ rastlanmadl.

Sonuç: Hem öznel hem de nesnel değerlendirmede total tiroidektomi esnasında sinir monitörizasyonu kullanıldığında, hastalarda ses kalitesinin korunduğu tespit edildi. IONM, tiroid ameliyatı sırasında EBSLN tespitinde etkili ve güvenli bir şekilde kullanılabilir.

Anahtar Sözcükler: Sinir monitörizasyonu, tiroidektomi, ses kalitesi
Address for Correspondence/Yazışma Adresi: Ahmet Kocakusak

University of Health Sciences, Haseki Training and Research Hospital, Clinic of General Surgery, Istanbul, Turkey

Phone: +90 5324484805 E-mail: ahmetkocakusak@yahoo.com ORCID ID: orcid.org/0000-0001-9685-6660 Received/Geliş Tarihi: 16 September 2017 Accepted/Kabul Tarihi: 28 October 2017
${ }^{1}$ Copyright 2018 by The Medical Bulletin of University of Health Sciences Haseki Training and Research Hospital
The Medical Bulletin of Haseki published by Galenos Yayınevi.

๑Telif Hakkı 2018 Sağlık Bilimleri Üniversitesi Haseki Eğitim ve Araştırma Hastanesi Haseki Tıp Bülteni, Galenos Yayınevi tarafından basıımıştır. 


\section{Introduction}

Thyroid gland surgery has possible serious complications due to the endocrine functions of the gland and the close anatomic relationship of the thyroid gland with the critical structures. Complications of thyroid surgery may be classified as minor and major. Major complications include injury to the recurrent laryngeal nerve (RLN) and the superior laryngeal nerve (SLN), bleeding (hematoma), hypoparathyroidism (hypocalcemia), and thyroid storm. Minor complications include seroma, hypertrophic scar formation, wound infection, and suture reaction (Table 1). Advancements in hemostasis, knowledge of the surgical anatomy and anesthetic and antiseptic strategies have led to improvements in the rates of complications in thyroid surgery. However, challenges to voice and respiratory outcomes still remain a significant area of concern for physicians and patients undergoing thyroid surgery.

We need intact laryngeal framework and intact laryngeal nerves for generation and consistency of voice. The incidence of RLN paralysis has been reported to vary from $1 \%$ to $17 \%(1-4)$. It is accepted as $1-2 \%$ for experienced surgeons. The incidence of injury to the external branch of the superior laryngeal nerve (EBSLN), which can cause weakness or complete paralysis of the ipsilateral muscle resulting in changes in voice quality, voice projection and the production of high-pitched sounds, has been reported to range from 0 to $58 \%$ (5-7).

Total thyroidectomy is associated with the risk of bilateral RLN injury. Currently, the gold standard technique for avoidance of RLN injury is still identifying the nerve early during dissection and maintaining positive visualization $(6,8)$. Due to anatomic variations such as non-recurrent nerve, extra laryngeal branching of the RLN, excessive bleeding may still result in iatrogenic nerve injury even with experienced surgeons. Besides, nerve conduction may be altered due to compression, strain, crushing, heat (bipolar or monopolar cauterization) or ischemic axonal injury (9). In order to identify and predict the function of the nerve, we may need new techniques such as intraoperative nerve monitoring (IONM). By the use of IONM, we can get electromyography (EMG) responses and able to control the integrity of the nerve. After getting positive EMG response, the possibility of normal laryngoscopic examination is very

\begin{tabular}{|l|l|}
\hline \multicolumn{2}{|l|}{ Table 1. Major and minor complications of thyroid surgery } \\
\hline Minor complications & Major complications \\
\hline Seroma & Bleeding (hematoma) \\
\hline Hypertrophic scar formation & Injury to RLN and SLN \\
\hline Wound infection & Hypoparathyroism \\
\hline Suture reaction & Thyroid storm \\
\hline RLN: Recurrent laryngeal nerve, SLN: Superior laryngeal nerve \\
\hline
\end{tabular}

high. However, in the absence of EMG response, there is still possibility of normal laryngoscopic examination. However, there is also possibility of undetection of laryngeal injury. It has been reported that among patients undergoing total thyroidectomy with IONM, the incidence of temporary paralysis and permanent paralysis was $1.6 \%$, $0.4 \%$, respectively (10).

Injury to EBSLN is usually underestimated in the case of RLN due to its relatively minor complications. However, it may also result in serious morbidity especially in singers, speakers or teachers who are voice professionals. EBSLN innervates the cricothyroid muscle and has a close relationship with the superior thyroid artery. Therefore, this nerve is under risk during dissection and ligation of the upper pole of the thyroid. The incidence of EBSLN injury has a wide range in the literature due to difficulties of functional assessment of the integrity of the EBSLN (6). Injury to EBSLN results in vocal fatigue and hoarseness of voice as well as aspiration and foreign body sensation in the throat. EBSLN integrity can be evaluated by the use of IONM.

In this study, we aimed to investigate postoperative voice quality following total thyroidectomy in patients with the diagnosis of multinodular goiter and well differentiated thyroid cancer. We investigated the efficiency and safety of IONM in identification of the EBSLN in preserving voice quality.

\section{Methods}

A total of 80 patients with the diagnosis of multinodular goiter and well differentiated thyroid cancer, who were scheduled for primary total thyroidectomy between May 2015 and March 2016 in Sultangazi Lütfiye Nuri Burat State Hospital in Istanbul, were included in the study. This study was approved by the local ethics committee (Haseki Training and Research Hospital/333-2015). The patients were informed about IONM and the surgery. All patients provided written informed consent. Those with lymph node metastasis, scheduled for neck dissection, and revision thyroid surgery were excluded from the study. All patients were examined preoperatively in the otolaryngology department with flexible fiberoptic laryngoscopy. Children, pregnant women, those with mental retardation and patients with a history of laryngeal surgery were excluded from the study. Surgical and medical records of all patients were examined. Age, sex, total operative time, comorbidities, ultrasonographic findings, and the size of the thyroid specimen were recorded. Preoperative and postoperative voice records were obtained for objective analysis. All patients were operated under neuromonitoring. Intraoperative EMG amplitudes and action potentials, initial and post-dissection RLN and 
EBSLN identification were recorded twice in $\mu \mathrm{V}$ for each nerve. The patients were examined postoperatively in the otolaryngology department for vocal cord pathologies.

\section{Voice Analysis}

Preoperative and postoperative subjective and objective voice assessments were performed for each patient. The Voice Handicap index-10 (VHI-10), which was translated into Turkish and studied for reliability in 2008, was applied preoperatively and postoperative $3^{\text {rd }}$ week (between 14-21 $1^{\text {st }}$ days) for subjective analysis (11). Voice records were obtained preoperatively and at the postoperative $3^{\text {rd }}$ week for objective analysis. In order to minimize the effect of edema, pain and nerve fatigue on voice quality we prefer $3^{\text {rd }}$ week control. All records were obtained in a silent room by a headphone with microphone. The patients were asked to phonate vowel /a/ at a comfortable habitus for at least five seconds. Voice samples were directly recorded on a computer and middle three-second part was edited. All records were sent to the Acoustic Laboratory of Çukurova University, Department of Otolaryngology and analyzed using the Praat acoustics software. Acoustic measurements related with frequency and perturbation of voice were recorded and analyzed. Disturbance of voice signal in the manner of frequency and amplitude is called perturbation. The most popular acoustic measurements for perturbation are jitter and shimmer. Jitter describes short-term (cycle to cycle) variability in fundamental frequency (FO) and shimmer describes variability in amplitude and intensity of voice signal (12). Preoperative and postoperative jitter percent (local \%), shimmer percent (local \%), shimmer in $\mathrm{dB}$ and fundamental frequency (FO) parameters were documented and compared in the study.

\section{Intraoperative Nerve Monitoring Technique}

All thyroid surgeries were performed under general anesthesia using short-acting muscle relaxants with IONM using a nerve integrity monitoring system (NIM, Dr. Langer, Germany). An endotracheal tube with an integrated surface electrode was inserted between the vocal folds by an anesthesiologist under direct vision during intubation. Neuromonitoring starts after resolution of the effects of the muscle relaxants. Repetitive stimulation of RLN and EBSLN with $1 \mathrm{~mA}$ to $2 \mathrm{~mA}$ was performed with a standard monopolar or bipolar probe. Proper stimulation was defined with both audible alarm of the NIM system and observation of recognizable EMG waveform $(>100 \mu \mathrm{V}$ for RLN and $>50 \mu \mathrm{V}$ for EBSLN). Initial EMG amplitudes for RNL were recorded with identification of RLN and final amplitudes after resection of the thyroid. Initial EMG amplitudes for EBSLN were recorded with prior to superior pole ligation and cricothyroid muscle twitch and final amplitudes were recorded after the resection of the thyroid.

\section{Statistical Analysis}

Statistical analysis was performed by the SPSS software package for Windows (Statistical Package for Social Sciences, version 17.0, SPSS Inc., Chicago, Illinois, USA). Quantitative variables were expressed as mean \pm standard deviation (SD) or median (IQR), whereas categorical variables as number and percentage. The normality of quantitative variables was analyzed by the KolmogorovSmirnov test and normally distributed variables were compared with the paired Sample t-test or compared with the Wilcoxon signed-ranks test when they did not normally distributed. Categorical variables were compared by a chi-square test or Fisher's exact test. A $p$ value less than 0.05 was considered statistically significant.

\section{Results}

A total of 80 patients (71 female and nine male), who underwent total thyroidectomy, were included in study. The age range was 30-70 years with a mean of 47.8 years. The total operative time range was 60-170 minutes with a mean of 102.7 minutes. All 160 RLNs were identified visually and electrically but only 151 EBSLNs (94.375\%, $151 / 160)$ could be identified electrically. Intraoperatively, we could identify the EBSLNs at both sides in 72 patients and at only one side in seven patients. We could not find EBSLN bilaterally in both sides in only one patient. A total of 151 EBSLNs could be electrically identified intraoperatively (94.375\%, 151/160).

\section{Electromyography Quantitative Data}

The mean EMG amplitude obtained for initial (identification of nerve) right RLN was $827.79 \mu \mathrm{V}$ (minimum: $156 \mu \mathrm{V}$, maximum: $1500 \mu \mathrm{V}, \mathrm{SD} \pm 277.320$ ) and the mean final amplitude (post-dissection) was 840.83 $\mu \mathrm{V}$ (minimum: $635 \mu \mathrm{V}$, maximum: $1660 \mu \mathrm{V}, \mathrm{SD} \pm 288.085$ ) with no significant difference $(p=0.291)$. The mean EMG amplitude for the initial left RLN and the final amplitude were $667.96 \mu \mathrm{V}$ (minimum: $297 \mu \mathrm{V}$, maximum: 1150

\begin{tabular}{|l|l|l|l|l|l|l|}
\hline \multicolumn{6}{|l|}{ Table 2. Mean electromyography amplitudes under neuromonitorization $(\boldsymbol{\mu} \mathbf{V})$} \\
\hline & RLN pre & RLN post & $p$ value & EBSLN pre & EBSLN post & p value \\
\hline Right & $827.79 \mu \mathrm{V}( \pm 277.320)$ & $840.83 \mu \mathrm{V}( \pm 288.085)$ & $p=0.291$ & $149.46 \mu \mathrm{V}( \pm 51.346)$ & $155.42 \mu \mathrm{V}( \pm 56.228)$ & $p=0.220$ \\
\hline Left & $667.96 \mu \mathrm{V}( \pm 212.065)$ & $689.17 \mu \mathrm{V}( \pm 167.932)$ & $p=0.363$ & $149.96 \mu \mathrm{V}( \pm 47.991)$ & $154.29 \mu \mathrm{V}( \pm 50.161)$ & $p=0.059$ \\
\hline RLN: Recurrent laryngeal nerve, EBSLN: External branch of the superior laryngeal nerve \\
\hline
\end{tabular}


$\mu \mathrm{V}$ SD \pm 212.065 ) and 689.17 $\mu \mathrm{V}$ (minimum: $367 \mu \mathrm{V}$, maximum: $1243 \mu \mathrm{V} S D \pm 167.932)$, respectively, similarly, with no significant difference $(p=0.363)$. The mean EMG amplitude for the initial right EBSLN (prior to ligation of the superior pole) and the final amplitude (post-dissection) were $149.46 \mu \mathrm{V}$ (minimum: $97 \mu \mathrm{V}$, maximum: $279 \mu \mathrm{V}$ SD $\pm 51.346)$ and $155.42 \mu \mathrm{V}$ (minimum:113 $\mu \mathrm{V}$, maximum: $295 \mu \mathrm{V}$ SD \pm 56.228$)$, respectively, with no significant difference $(p=0.220)$. The mean EMG amplitude initial left EBSLN and the final amplitude were $149.96 \mu \mathrm{V}$ (minimum: $97 \mu \mathrm{V}$, maximum: $316 \mu \mathrm{V} \mathrm{SD} \pm 47.991)$ and $154.29 \mu \mathrm{V}$ (minimum: $89 \mu \mathrm{V}$, maximum: $315 \mu \mathrm{V}$ SD \pm 50.161 ), respectively, with no significant difference $(p=0.059)$ (Table 2). A proper stimulation was accepted through the observation of the cricothyroid muscle twitch and recognizable EMG waveform.

\section{Voice Analysis}

The mean preoperative acoustic parameters of voice signals (jitter percent (local \%), shimmer percent (local $\%)$, shimmer in $d B(d B)$ and fundamental frequency (F0 median) were $0.572,4.327,0.474 \mathrm{~dB}$ and 215.541, respectively. The mean postoperative acoustic parameters were $0.652,4.722,0.456 \mathrm{~dB}$ and 209.785 , respectively, with no significant difference $(p=0.943, p=0.819$, $p=0.887$, and $p=0.521$, respectively) (Table 3 ).

During subjective analysis, the mean preoperative and postoperative $\mathrm{VHI}-10$ ratings were 5.60/40 and 8.50/40, respectively, without a significant difference $(p=0.123)$.

\begin{tabular}{|c|c|c|c|}
\hline & Preoperative & Postoperative & $p$ value \\
\hline Jitter (local \%) & 0.572 & 0.652 & 0.943 \\
\hline Shimmer (local \%) & 4.327 & 4.722 & 0.819 \\
\hline Shimmer (dB) & 0.474 & 0.456 & 0.887 \\
\hline $\begin{array}{l}\text { Fundamental } \\
\text { frequency (F0 median) }\end{array}$ & 215.541 & 209.785 & 0.521 \\
\hline VHI-10 & 5.60 & 8.50 & 0.123 \\
\hline
\end{tabular}

\begin{tabular}{|l|l|l|}
\hline Table 4. Complications & (n) & (\%) \\
\hline Transient vc paralysis & $7 / 160$ & 4.375 \\
\hline Permanent vc paralysis & $0 / 160$ & 0 \\
\hline Transient hypocalcemia & $11 / 80$ & 13.75 \\
\hline Permanent hypocalcemia & 0 & 0 \\
\hline Infection & 0 & 0 \\
\hline Hematoma & 0 & 0 \\
\hline $\begin{array}{l}\text { n: Number of patients for hypocalcemia/number of nerve under risk (for vocal } \\
\text { cord paralysis) }\end{array}$ \\
\hline
\end{tabular}

Histopatological examination revealed malignancy (papillary carcinoma) in 12 patients and benign nodular or multinodular disease in 68 patients. Management of 12 malignant cases was provided with cooperation of endocrinology and nuclear medicine departments. We did not observe clinical or radiological metastatic lymph nodes in the neck, thus, none of the patients required neck dissection.

Laryngoscopy on the first postoperative day revealed 7 vocal fold paralyses in 160 RLN under risk. Three of them were found to be recovered at the first month of follow-up and 4 in the $3^{\text {rd }}$ month, and all these paralyses were accepted as temporary paralysis. We did not observe bilateral vocal fold paralysis. The incidence of temporary and permanent vocal fold paralysis was $4.375 \%$ (7/160) and $0 \%(0 / 160)$, respectively.

We did not observe permanent hypocalcaemia; only 11 patients developed transient hypocalcaemia and easily recovered with calcium replacement. None of the patients developed hematoma or wound infection (Table 4).

\section{Discussion}

Neuromonitoring is one of the most important technologic advancements in modern thyroid surgery. It is accepted as a helpful technique for preservation of both airway and vocal functions. In case of absence of consensus for IONM usage, the guideline released by the American Academy of Otolaryngology Head and Neck Surgery Foundation advising IONM usage during thyroid surgery for voice quality preservation may be referred (13). Both the German Association of Endocrine Surgeons and the International Neural Monitoring Study Group advise the usage of IONM in all thyroid surgeries, but the American Head and Neck Society recommends neuromonitoring only in patients with thyroid cancer $(14,15)$.

Dysphonia related with thyroid surgery may result from neural and non-neural etiologies. Neural etiologies include RLN or EBSLN injury. Non-neural etiologies include cricothyroid muscle injury, strap muscle injury, local edema, hematoma, and intubation trauma (16).

In several studies, subjective voice complaints without laryngeal nerve injury have been reported in 30\% to $87 \%$ of patients (7,17-19). Previous similar studies including objective vocal assessment after thyroid surgery reported reduced fundamental frequency, diminished vocal range, decreased maximum sound pressure and increased vocal jitter (20-22). In this study, our patients commonly described transient vocal changes during early recovery period, but we did not observe any significant difference between preoperative and postoperative subjective voice assessment at the $3^{\text {rd }}$ week of the follow-up. Additionally, we did not find any significant 
difference between preoperative and postoperative acoustic parameters in objective voice assessment (jitter, shimmer and fundamental frequency). Muscle trauma related with intraoperative surgical manipulations may result in long-lasting dysphagia and pain. In addition, transient myositis or direct injury to cricothyroid muscle is one of the important causes of non-neural etiologies of dysphonia (20). Preservation of objective voice quality in our study was thought to be related with identification and preservation of both the RLN and EBSLN with IONM. EBSLN innervates the cricothyroid muscle, causing vocal fold lengthening and tension. The paralysis of the EBSLN causes inferior displacement of the affected cord, resulting in vocal fatigue and decreased voice pitch. Direct visual identification of the EBSLN is not possible in all cases but detection of recognizable EMG amplitude with the help of IONM and observation of the cricothyroid muscle twitch usually reveal valuable information for the integrity of the nerve.

In this study, we did not observe a significant difference between initial and final mean EMG amplitudes for both the RLN and the EBSLN. All RLNs were effectively detected with IONM and visual identification, but only 151 EBSLNs could be identified electrically $(94.375 \%, 151 / 160)$. These results gave us reliable data for prediction of postoperative integrity of the nerves.

Kandil et al. (23) reported lower mean EMG amplitudes for EBSLN comparing with RLN in their study in 2015. Similarly, in our study, we observed lower mean EMG amplitudes for EBLSN. This is thought to be related with smaller anatomic size of the EBSLN compared to the RLN.

In general practice, direct visual identification of the EBSLN is not possible for all patients because of subfascial (deep to inferior constrictor muscle fascia) placement of the nerve (8). IONM help us stimulate and identify the nerve, even in subfascial located ones. Darr et al. (24) reported identification of the EBSLN with IONM in 100\% of patients. In their study, they investigated 29 EBSLN in 22 patients; achieved positive EMG response and ipsilateral cricothyroid muscle twitch in all patients. They advocate the $100 \%$ possibility of EBSLN identification during thyroid surgery. Hurtado-Lopez et al. (25) reported in another comparative prospective study that IONM was found to be significantly superior to direct visual identification of the EBSLN. In their study, IONM identified 234 of 240 EBSLNs (97.5\%) whereas 190 (79.1\%) were identified visually. Similarly, in our study, we could identify the EBSLN with a very high rate $(94.375 \%, 151 / 160)$ by the help of IONM prior to superior pole ligation. Successful identification was defined with recognizable EMG amplitude and ipsilateral cricothyroid muscle twitch. Due to difficult dissection and resulting minor problems, it is not strictly advised to look for the EBSLN during thyroid surgery as a routine by some authors. It is advised to preserve the nerve only if it comes into view. Recent studies showed a very high rate of EBSLN identification with the help of IONM, similar to our results. Because of the absence of a control group in our study, we could not comment that EBSLN identification with IONM was the only factor for voice quality preservation. However, we advise identification of both the RLN and EBSLN in order to preserve the voice quality.

Although we get EMG responses for all RLNs, we experienced 7 transient vocal cord paralyses. Early recovery of paralysis led us to think that the reasons might be related with excessive manipulation and multiple stimulation of the nerve. Since the final amplitudes were reliable predictors of intact vocal cord mobility, these final amplitudes relieve the surgeon's mind for the function of the vocal cord. Shindo and Chheda (26) reported in their study in 2007 that RLN monitoring did not reduce the incidence of transient or permanent vocal cord paralysis. Similar to this result, in another comprehensive comparative study, Calo et al. (27) did not show a significant difference between direct visualization and IONM usage for the incidence of either transient or permanent vocal cord paralysis. Pisanu et al. (28) investigated 20 studies comparing direct visualization and IONM in a metaanalysis in 2014. A total of 35513 nerves (24038 IONM, 11475 direct visualization) were included in this metaanalysis and the incidence of paralysis was found to be $3.47 \%$ in IONM group and $3.67 \%$ in direct vision group with no significant difference. However Barczynski et al. (29) reported a decreased incidence of transient paralysis with IONM usage especially in high-risk patients. Frattini et al. (30) reported a decrease in the incidence of both transient and permanent paralysis in their comparative study with thyroid cancer patients (76 IONM, 76 direct vision). There have been comparative studies stating that IONM did not decrease the incidence of laryngeal nerve injuries. However, neuromonitoring is a very effective and safe method for identification and preservation of both the RLN and the EBSLN. Identification of both the RLN and the EBSLN by the help of IONM ensures the surgeon for airway and voice preservation. Besides, legal problems may also be an important indication for neuromonitoring.

\section{Conclusion}

In this study, we observed stable voice quality after total thyroidectomy under neuromonitoring according to objective and subjective voice assessments. Neuromonitoring is a very effective and safe method for identification of both the RLN and the EBSLN with a very high rate of identification. In order to preserve the quality 
of voice, we advise to identify both the RLN and the EBSLN with the help of IONM. This study was designed as a selfcontrolled study. Absence of a control group is the weak point of the study, but both objective and subjective voice analyses and prospective design are the strong points. Further multicenter prospective randomized studies with control groups will provide more enlightening explanations and information in this field.

\section{Author Contributions}

Surgical and Medical Practices: E.Ç., T.D. Consept: E.Ç., T.D. Design: S.F., E.H. Data Collection or Processing: Ö.S., A.K. Analysis or Interpretation: E.Ç., Ö.S. Literature Search: S.F., E.H. Writing: A.K., Ö.S.

Conflict of Interest: The authors declared no potential conflicts of interest with respect to the research, authorship, and publication of this article.

Financial Disclosure: The authors declared that this study has received no financial support.

\section{References}

1. Bhattacharyya N, Fried MP. Assessment of the morbidity and complications of total thyroidectomy. Arch Otolaryngol Head Neck Surg 2002;128:389-92.

2. Hermann M, Alk G, Roka R, Glaser K, Freissmuth M. Laryngeal recurrent nerve injury in surgery for benign thyroid diseases: effect of nerve dissection and impact of individual surgeon in more than 27,000 nerves at risk. Ann Surg 2002;235:261-8.

3. Chiang FY, Wang LF, Huang YF, Lee KW, Kuo WR. Recurrent laryngeal nerve palsy after thyroidectomy with routine identification of the recurrent laryngeal nerve. Surgery 2005; 137:342-7.

4. Seven H, Calis AB, Vural C, Turgut S. Microscopic thyroidectomy: a prospective controlled trial. Eur Arch Otorhinolaryngol 2005;262:41-4.

5. Dralle H, Sekulla C, Haerting J, et al. Risk factors of paralysis and functional outcome after recurrent laryngeal nerve monitoring in thyroid surgery. Surgery 2004;136:1310-22.

6. Barczynski M, Randolph GW, Cernea CR, et al. External branch of the superior laryngeal nerve monitoring during thyroid and parathyroid surgery: International Neural Monitoring Study Group standards guideline statement. Laryngoscope 2013;123(Suppl 4):S1-14.

7. Sinagra DL, Montesinos MR, Tacchi VA, et al. Voice changes after thyroidectomy without recurrent laryngeal nerve injury. J Am Coll Surg 2004;199:556-60.

8. Friedman M, LoSavio P, Ibrahim H. Superior laryngeal nerve identification and preservation in thyroidectomy. Arch Otolaryngol Head Neck Surg 2002;128:296-303.

9. Shaha AR. Management of the neck in thyroid cancer. Otolaryngol Clin North Am 1998;31:823-31.

10. Miller MC, Spiegel JR. Identification and monitoring of the recurrent laryngeal nerve during thyroidectomy. Surg Oncol Clin N Am 2008;17:121-44.
11. Kilic MA, Okur E, Yildirim I, et al. Reliability and validity of the Turkish version of the Voice Handicap Index. Kulak Burun Bogaz Ihtis Derg 2008;18:139-47.

12. CW Cummings, PF., BH Haughey, T Robbins, JR Thomas, LA Harker, MA Richardson, DE Schuller Chapter 17: Voice Analysis in Cummings Otolaryngology-Head\&Neck Surgery, C. Cumminngs, Editor. 2007, Elsevier, Mosby.

13. Chandrasekhar SS, Randolph GW, Seidman MD, et al. Clinical practice guideline: improving voice outcomes after thyroid surgery. Otolaryngol Head Neck Surg 2013;148(Suppl 6):S137.

14. Randolph GW, Dralle H. Electrophysiologic recurrent laryngeal nerve monitoring during thyroid and parathyroid surgery: international standards guideline statement. Laryngoscope 2011;121(Suppl 1):S1-16.

15. Musholt TJ, Clerici T, Dralle H. German Association of Endocrine Surgeons practice guidelines for the surgical treatment of benign thyroid disease. Langenbecks Arch Surg 2011;396:639-49.

16. Randolph GW, Sritharan N, Song P, Franco R Jr, Kamani D, Woodson G. Thyroidectomy in the professional singer-neural monitored surgical outcomes. Thyroid 2015;25:665-71.

17. de Pedro Netto I, Fae A, Vartanian JG, et al. Voice and vocal self-assessment after thyroidectomy. Head Neck 2006;28:1106-14.

18. Page C, Zaatar R, Biet A, Strunski V. Subjective voice assessment after thyroid surgery: a prospective study of 395 patients. Indian J Med Sci 2007;61:448-54.

19. Rosato L, Carlevato MT, De Toma G, Avenia N. Recurrent laryngeal nerve damage and phonetic modifications after total thyroidectomy: surgical malpractice only or predictable sequence? World J Surg 2005;29:780-4.

20. Hong KH, Kim YK. Phonatory characteristics of patients undergoing thyroidectomy without laryngeal nerve injury. Otolaryngol Head Neck Surg 1997;117:399-404.

21. Debruyne F, Ostyn F, Delaere P, Wellens W. Acoustic analysis of the speaking voice after thyroidectomy. J Voice 1997;11:47982.

22. Debruyne F, Ostyn F, Delaere P, Wellens W, Decoster W. Temporary voice changes after uncomplicated thyroidectomy. Acta Otorhinolaryngol Belg 1997;51:137-40.

23. Kandil E, Mohamed SE, Deniwar A, et al. Electrophysiologic identification and monitoring of the external branch of superior laryngeal nerve during thyroidectomy. Laryngoscope 2015;125:1996-2000.

24. Darr EA, Tufano RP, Ozdemir S, Kamani D, Hurwitz S, Randolph G. Superior laryngeal nerve quantitative intraoperative monitoring is possible in all thyroid surgeries. Laryngoscope 2014; 124:1035-41.

25. Hurtado-Lopez LM, Diaz Hernandez PI, Basurto-Kubaet E, Zaldivar-Ramirez FR, Pulido-Cejudo A. Efficacy of Intraoperative Neuro-Monitoring to Localize the External Branch of the Superior Laryngeal Nerve. Thyroid 2016;26:174-8.

26. Shindo M, Chheda NN. Incidence of vocal cord paralysis with and without recurrent laryngeal nerve monitoring 
during thyroidectomy. Arch Otolaryngol Head Neck Surg 2007;133:481-5

27. Calo, PG, Pisano G, Medas F, et al. Intraoperative recurrent laryngeal nerve monitoring in thyroid surgery: is it really useful? Clin Ter 2013;164:193-8.

28. Pisanu A, Porceddu G, Podda M, Cois A, Uccheddu A. Systematic review with meta-analysis of studies comparing intraoperative neuromonitoring of recurrent laryngeal nerves versus visualization alone during thyroidectomy. J Surg Res 2014;188:152-61.

29. Barczynski M, Konturek A, Cichon S. Randomized clinical trial of visualization versus neuromonitoring of recurrent laryngeal nerves during thyroidectomy. Br J Surg 2009;96:240-6.

30. Frattini F, Mangano A, Boni L, Rausei S, Biondi A, Dionigi G. Intraoperative neuromonitoring for thyroid malignancy surgery: technical notes and results from a retrospective series. Updates Surg 2010;62:183-7. 